\title{
Early Diagnosis of Hemoglobinopathies
}

\author{
VERLE E. HEADINGS, ${ }^{(27)}$ STEPHEN I. O. ANYAIBE, SYAMA P. BHATTACHARYA, \\ AND ERNEST L. HOPKINS \\ Division of Medical Genetics, Department of Pediatrics and Child Health, The Center for Sickle Cell Disease (V.E.H., \\ S.I.O.A., and S.P.B.), and Department of Obstetrics and Gynecology (E.L.H.), Howard University College of \\ Medicine, Washington, DC (USA)
}

\section{Summary}

Antibodies specific for human hemoglobins $\mathrm{F}, \mathrm{A}, \mathrm{S}$, and $\mathrm{C}$ were isolated by affinity chromatography from antisera produced in rabbits and goats. These reagents were shown to possess adequate sensitivity for identifying and quantifying hemoglobins $A, S$, and $C$ in cord blood by radial immunodiffusion (RID). Furthermore, single immunodiffusion plates combining up to three of the antibodies at differing concentrations produced up to three nonoverlapping immunoprecipitin rings, retaining the capability for identifying multiple hemoglobins by a single application of hemolyzed whole blood to the RID plate.

Isolated antibodies were conjugated with fluorescein isothiocyanate and incubated with red blood cells which were obtained from placental cord blood or from amniotic fluid obtained by amniocentesis and maternal venous blood at 16-20 weeks of gestation, and suspended in a thin layer of agar. Using antibodies against hemoglobins $F, A$, and $S$ this method proved to possess sufficient sensitivity for detecting each of the respective hemoglobins in individual cells in all of the above classes of specimens.

Since the red blood cells obtained by amniocentesis are potentially a mixture of fetal and maternal cells the proportion of $F$ cells to $A$ cells in amniotic fluid and in maternal venous blood were estimated. In 33 such sequential specimen pairs, 29 contained a higher $\mathbf{F}$ cell to $A$ cell ratio in amniotic fluid than in maternal blood.

Red blood cells from maternal blood and from amniotic fluid were incubated in vitro with $\mathrm{L}-\mathrm{I}^{14} \mathrm{C} \mid$ serine. Incorporation of the serine into cells was identified by autoradiography. Since a substantial proportion of fetal red blood cells are synthetically active this provides a method for identifying hemoglobin phenotype in fetal-origin cells in a fetal-maternal mixture. Initial experience with a short series of specimens examined in this manner indicates that in amniotic fluid the proportion of cells which contain both hemoglobin and $\mathrm{L}-\left[^{14} \mathrm{C}\right]$ serine is typically higher than in maternal venous blood. Diagnostic accuracy for hemoglobin phenotypes of the fetus by the combination of autoradiography and fluorescent cytoimmunodiffusion is being tested currently in a substantial unselected sample of amniotic fluid specimens. Criteria for definitive diagnosis of SS phenotype in the fetus are fluorescent anti-S pattern in synthetically active cells, absence or rare occurrence of fluorescent anti-A pattern in such active cells, and a higher relative frequency of synthetically active $F$ cells in amniotic fluid than in maternal blood.

\section{Speculation}

The specificity and sensitivity of antibodies to hemoglobin variants combined with the simplicity of the method of radial immunodiffusion offers promise for universally available screening for hemoglobinopathies in cord blood.

The sensitivity of these same antibodies when conjugated with fluorescein isothiocyanate appears to provide a diagnostic approach to hemoglobinopathies in the fetus which circumvents the need to expose the fetus and mother to risks of amnioscopy and venipuncture of the fetal system.

The class of genetic disorders known as hemoglobinopathies has served as the most productive model system for probing molecular mechanisms underlying inherited human disease. In given populations some hemoglobinopathies occur in relatively higher frequencies than do most other inherited diseases.

Attention to early diagnosis of hemoglobinopathies in either the prenatal or early postnatal period occurred relatively recently in contrast to inborn errors of metabolism, such as phenylketonuria and galactosemia. Impetus for development and application of screening methodology generally comes from such factors as frequency of the given disease, prognosis, acceptable options for effective treatment or prevention of the given disease, promising technical methodologies, and a measure of advocacy for the requisite research from the concerned population. For the sickling disorders the factors of relatively high frequency and high morbidity and mortality rates have been known for a long time. Increasing numbers of options for prevention or treatment are in differing stages of development (9). Methodologies for diagnosis of hemoglobinopathies in the newborn infant and fetus have also shown substantial progress and it is the purpose of this report to present new developments in this area.

Diagnosis of sickle cell disease is currently attempted on cord blood by a combination of electrophoresis techniques. Electrophoresis of hemoglobins on cellulose acetate as is applied routinely after the neonatal period does not achieve consistently satisfactory resolution of hemoglobulins $F$ and $A$ in the presence of the overwhelming quantity of $\mathrm{Hb} F$ in cord blood. Not infrequently this would lead to diagnosing homozygous $S$ in infants who in fact have either sickle cell trait (Hb AS) or sickle-thalassemia (Hb $\mathrm{S}$-thal). This therefore has led to the practice in some centers of screening all cord blood on cellulose acetate, or a medium achieving comparable separation, followed by a second electrophoresis of all variant specimens in a citrate acid agar gel system, which reportedly achieves the necessary resolution of $\mathrm{Hb} F$ and $A(4,15$, 22). However, the citrate acid agar gel system, used for cord blood, has not been uniformly reliable in all other laboratories. At a minimum it is apparent that this methodology requires an unusual degree of effort on quality control and technician expertise, which may not be available in clinical laboratories outside the larger medical centers. An alternative such as a centralized laboratory for cord blood screening to which blood specimens are mailed defeats a potentially important objective of the screening service, namely, counseling, and, where indicated, planning a management strategy before the infant leaves the hospital.

Hemoglobins in cord blood are effectively separated by microcolumn chromatography, however, this presents limitations of specificity of identification (20).

The immunochemical methodology of RID to be presented here for diagnosing hemoglobinopathies in the newborn infant offers minimal equipment investment by hospital-based labora- 
tories, minimal technician expertise and effort, and a diagnosis before the usual discharge date. This assumes that simple RID test kits would become commercially available for this system as is the case presently for various other proteins. In certain of these respects it appears to be more advantageous than either chromatography or radioimmunoassay $(6,10)$. We believe that one of the major benefits of an RID test system may be to enable the many smaller hospital-based laboratories or those with limited numbers of clientele at risk to offer newborn screening for sickling disorders.

Methodologies for prenatal diagnosis must adapt to the relative inaccessibility of fetal blood. These can be resolved into methods for obtaining the specimen and methods for diagnosing the hemoglobin phenotype of the fetus. Using an endoscope, venipuncture of placental blood vessels reportedly has secured fetal blood in $90 \%$ of trials (1). Both placental aspiration and fetoscopy with aspiration from a placental vein thus far pose an undesirable level of risk for short term complications, and in some hands fail to secure sufficient fetal blood in all cases for diagnosis of hemoglobinopathies by the globin chain synthesis method $(1,12,17)$. Invasion of the fetal system, whether by venipuncture or placental aspiration, also poses potential intermediate or long term risks to the developing individual which are difficult to evaluate without subjecting a substantial number of human fetuses to the procedure. The technique of amniocentesis in principle imposes virtually no direct trauma on the fetus or the placenta and controlled studies have revealed no significant short or intermediate term risk to the fetus $(11,14,19)$. A large majority of so-called nonbloody fluid specimens obtained by amniocentesis contain a few fetal red cells (3).

Diagnostic methods have focused on essentially three different approaches. One approach requires 5-10 $\mu 1$ of fetal blood which frequently can be obtained by venipuncture of a fetal vein or by needle aspiration of a mixed sample of maternal and fetal blood from the placenta. The diagnosis is achieved by isotopic labeling of newly synthesized globin chains in the fetal reticulocytes in vitro after which labeled hemoglobins are separated and identified by chromatography or electrophoresis $(13,16)$. The second and third methods are adapted to achieving diagnosis of hemoglobin phenotype in single erythrocytes commonly obtained by amniocentesis. Specific fluorescent antibodies against various hemoglobins have allowed identification in individual erythrocytes, including those obtained by amniocentesis $(3,7,8)$. The third method utilizes electrophoresis of the contents of single erythrocytes (2). Further developments with the fluorescent antibody method for identifying hemoglobins in individual fetal cells will be presented here. Finally, we will present overall strategies for early diagnosis in either the fetus or newborn infant which offer some promise for universal application of more effective preventive management of sickling disorders.

\section{MATERIALS AND METHODS}

\section{ISOLATION OF HEMOGLOBINS}

Hemoglobins F, A, C, and S were isolated by column chromatography on DEAE-cellulose A-50 (8) followed by electrophoretic separation in a horizontal block of polyacrylamide using TrisEDTA-boric acid buffer, $\mathrm{pH}$ 8.6. Homogeneity of the isolated products were tested by electrophoresis on cellulose polyacetate and acid agar ( $1 \%$ Difco agar in $0.05 \mathrm{M}$ sodium citrate buffer, $\mathrm{pH}$ 5.8).

\section{PREPARATION OF SPECIFIC ANTISERA}

Five milligrams of purified $\mathrm{Hb} F$ in Freund's complete adjuvant were administered to rabbits ip at six weekly intervals. This was followed 1 week later by $1 \mathrm{mg}$ in physiological saline iv and at approximately monthly intervals thereafter. Six and 7 days after each iv injection up to $40 \mathrm{ml}$ blood were collected from the marginal vein of the ear. The serum was tested for specific activity and then stored at $-80^{\circ}$ until further processing.
Five milligrams of either purified $\mathrm{Hb}, \mathrm{A}, \mathrm{S}$, or $\mathrm{C}$ in $1 \mathrm{ml}$ Freund's complete adjuvant were administered to goats im in multiple sites at three biweekly intervals. This was followed 1 week later and at approximately monthly intervals with $1 \mathrm{mg}$ in physiologic saline into the external jugular vein. Frequently the latter procedure was accompanied by an anaphylactic reaction, which was treated by administration of epinephrine im. Six and 7 days later up to $200 \mathrm{ml}$ blood were collected from the external jugular vein. The serum was tested by double immunodiffusion and stored at $-80^{\circ}$ until further processing.

Specific antibodies were isolated by affinity chromatography as previously described (8).

\section{SOURCE OF ERYTHROCYTES}

Placental cord blood was obtained from term deliveries. Maternal venous blood ( $1 \mathrm{ml}$ in EDTA) and amniotic fluid (30-50 ml in sterile bottles) were obtained from women between 16 and 20 weeks of gestation who presented to Howard University Hospital for saline-induced termination of pregnancy with indications unrelated to this study. After localization of the placenta by ultrasonography and before introduction of hypertonic saline into the amniotic sac, $30-50 \mathrm{ml}$ amniotic fluid were removed through a no. 18 gauge needle which was inserted approximately midway between the symphysis and umbilicus.

\section{CHARACTERIZATION OF ANTIBODY SPECIFICITY}

Antibody specificity for the immunizing hemoglobin was tested by double immunodiffusion and by RID at four hemoglobin concentrations which spanned the range likely to be encountered in a test blood specimen, essentially as previously described (23).

\section{QUANTITATION OF HEMOGLOBINS BY RID}

The preparation of plates for RID was modified in the following manner from that previously reported (23). Three isolated antibodies were mixed together in the agar plates to enable identification of any of three hemoglobins on a single plate. Concentrations of each of the antibodies in the agar were adjusted to assure nonoverlapping precipitin rings for each of three hemoglobins (Hb ACS) when tested within a range of concentrations anticipated in cord blood of either a heterozygote or homozygote for a given variant. Packed erythrocytes from cord blood were lysed by addition of deionized water in $1: 1$ volume proportions. This lysate was subsequently diluted 200 -fold when quantifying $\mathrm{Hbs}, \mathrm{A}, \mathrm{S}$, or C. This dilution yielded concentrations of specific hemoglobins in the range of $0.5-1 \mathrm{mg} / \mathrm{ml}$. Four microliters of the diluted specimens were introduced into each well on the RID plate.

\section{IDENTIFICATION OF HEMOGLOBINS IN SINGLE CELLS}

Antibodies isolated by affinity chromatography were subsequently labeled with fluorescein isothiocyanate (8) and the conjugated product was adjusted to $2 \mathrm{mg}$ protein $/ \mathrm{ml}$.

Within $24 \mathrm{hr}$ the amniotic fluid was filtered through cloth followed by glass wool to remove debris. Twenty-five milliliters of the filtrate were centrifuged at $480 \times g$. Recently $10 \mathrm{ml}$ filtrate has proved satisfactory. The sediment was resuspended in $10 \mathrm{ml}$ physiologic saline, centrifuged again, and $9.5 \mathrm{ml}$ of the supernatant discarded. The remaining volume containing suspended cells was equilibrated to $40^{\circ}$ and then mixed with $1.5 \mathrm{ml}$ melted agar $(1.25 \%)$ in physiologic saline at $40^{\circ}$. Uniform mixture was achieved by bubbling with air in a water bath at $40^{\circ}$.

Erythrocytes from maternal venous blood were washed three times in physiologic saline. Ten or $5 \mu \mathrm{l}$ packed cells were mixed with $2 \mathrm{ml}$ melted agar (1\%) as described above. The agar was layered onto glass slides to a thickness of $0.025 \mathrm{~mm}$, allowed to gel, and gel sections incubated in $0.3 \%$ Triton-X and in either labeled anti-F, anti-A, or anti-S as described previously (8). The relative frequencies of cells containing given hemoglobins were 
obtained from photographs through a Leitz Orthoplan fluorescence microscope.

One milliliter of red blood cells or amniotic fluid cells were washed with NKM solution $(0.13 \mathrm{M} \mathrm{NaCl}, 0.005 \mathrm{M} \mathrm{KCl}, 0.0075$ $\mathrm{M} \mathrm{MgCl}_{2}$ containing 5\% sucrose) and then incubated with $20 \mu \mathrm{Ci}$ $\left.\mathrm{L}-\mathrm{I}^{14} \mathrm{C}\right]$ serine for $3 \mathrm{hr}$. The specimens were then washed three times in NKM solution and the cells suspended in agar as done routinely for cytoimmunodiffusion (8). The cell suspension was layered onto a glass slide, allowed to gel, incubated in fluorescent labeled antibody and $0.3 \%$ Triton-X for $1 \mathrm{hr}$, washed three times in physiologic saline, dehydrated at room temperature, and covered with Kodak NTB 3 emulsion. The emulsion was exposed to the radiation for a minimum of $2 \mathrm{hr}$, then washed in Kodak developer solution for $10 \mathrm{~min}$, rinsed in physiologic saline, fixed with Kodak fixer-saline for $5 \mathrm{~min}$, and rinsed in saline for $5 \mathrm{~min}$. This short exposure time is made possible by the cells being suspended in an extremely thin layer of dried agar. The short interval minimizes distortion of the fluorescent immunoprecipitate grain pattern.

\section{RESULTS}

\section{SPECIFICITY OF ANTIBODIES}

The isolated antibodies for anti-Hb A, anti-Hb C, anti $\mathrm{Hb} \mathrm{S}$, and anti-Hb $\mathrm{F}$ were tested initially by double immunodiffusion for absence of cross-reacting activity. Absence of cross reactivity is shown in each instance when tested against $1 \mathrm{mg} / \mathrm{ml}$ of the given hemoglobins (Fig. 1).

\section{QUANTITATION OF HEMOGLOBINS IN CORD BLOOD}

The concentrations of anti-A, anti-C, and anti-S were adjusted so as to yield nonoverlapping ring diameters when reacted with hemoglobin. The antibody concentrations respectively were 1.8 $\mathrm{mg} / \mathrm{ml}, 1.2 \mathrm{mg} / \mathrm{ml}$, and $0.6 \mathrm{mg} / \mathrm{ml}$. Dose-response curves for purified Hbs A, C, and $\mathrm{S}$ were linear over four hemoglobin concentrations spanning the anticipated ranges in cord blood for homozygotes and heterozygotes (Fig. 2). This range was established empirically for the antibody preparations in our laboratory. Two hundred-fold dilutions of cord bloods lie approximately midway on these standard curves. If the A ring diameter were to fall below the range of selected standards, this would be indication to conduct followup testing to exclude $\beta$-thalassemia or sickle thalassemia. Retesting a less dilute aliquot would clearly allow a sickle- $\beta^{+}$-thalassemia diagnosis from the standard curve. In any case, as with other diagnostic methods, sickle-thal is distinguished from $\mathrm{Hb} \mathrm{AS}$ by relative proportions of the hemoglobins along with appropriate family studies.

Double and triple precipitin ring patterns discriminated between known mixtures of purified $\mathrm{Hbs}, \mathrm{A}, \mathrm{C}$, and $\mathrm{S}$. The same was also shown for a small sampling of cord blood specimens (Fig. 3). The relative proportions of antibodies in the plate agar were selected to keep the $\mathrm{Hb} A$ ring the smallest of the three rings. Thus, deficiencies in $\mathrm{Hb}$ A such as in sickle- $\beta$-thalassemia would diminish the $A$ ring diameter without overlapping the $S$ ring diameter.

The specificities of the antibodies were documented by the double immunodiffusion patterns in Figure 1 and substantiated in Figure 3 by immunoprecipitin ring patterns for artificial mixtures of purified hemoglobins and of cord bloods. The observed number of rings always corresponded to the predicted number for each mixture and the ring diameters for each hemoglobin in the mixtures corresponded to ring diameters for the respective hemoglobins tested alone. Phenotype of each cord blood was verified independently by electrophoresis on citrate acid agar plates.

\section{IDENTIFICATION OF HEMOGLOBINS IN FETAL ERYTHROCYTES}

By the method of cytoimmunodiffusion relative frequencies of cells containing $\mathrm{Hb} \mathrm{A}, \mathrm{Hb} \mathrm{S}$, and $\mathrm{Hb} \mathrm{F}$ were counted in fluid

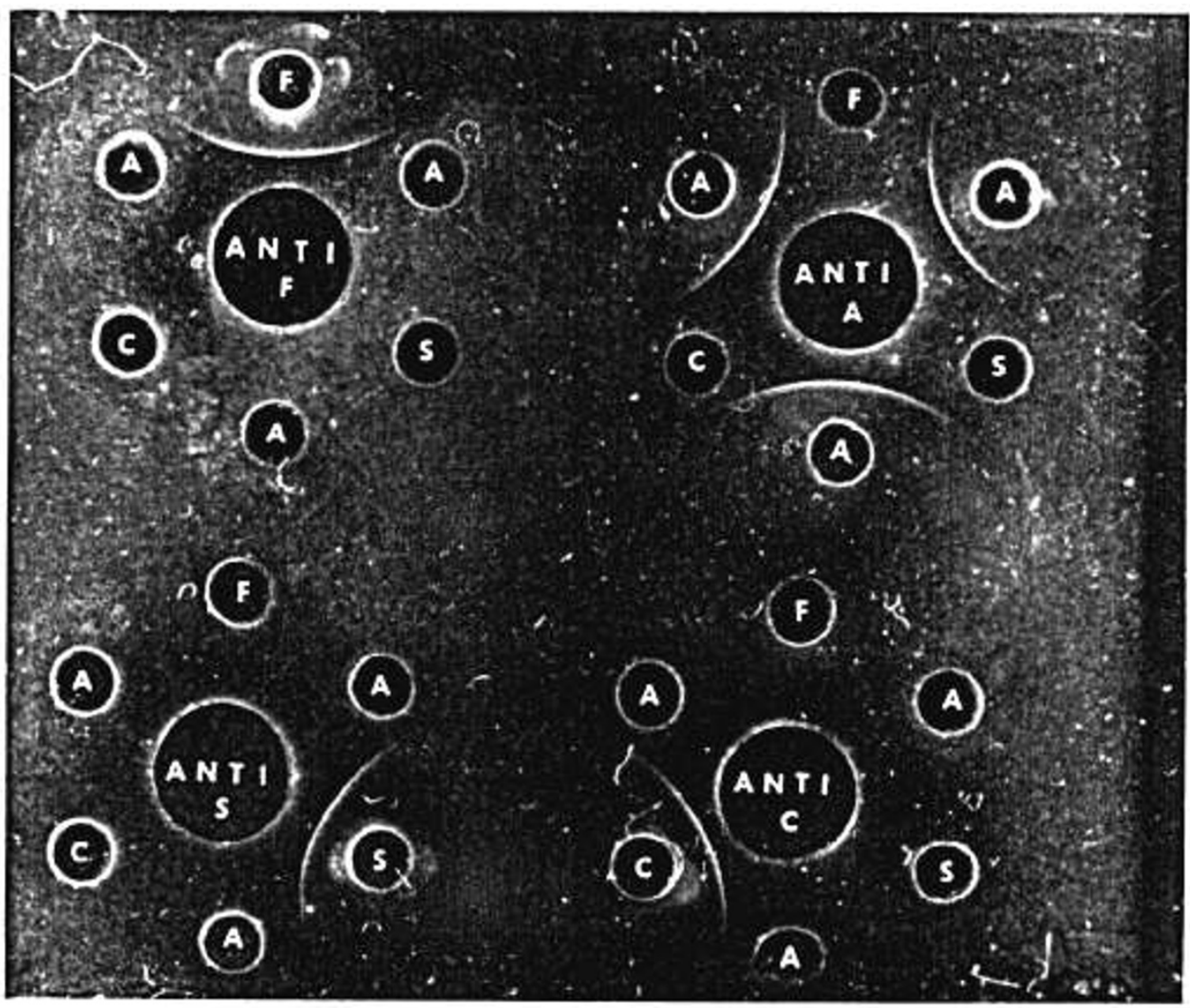

Fig. 1. Specificity of isolated antibodies ( $1 \mathrm{mg}$ protein $/ \mathrm{ml}$ ) as demonstrated by double immunodiffusion. F, A, S, and C are purified hemoglobins in concentrations of $1 \mathrm{mg} / \mathrm{ml}$. 

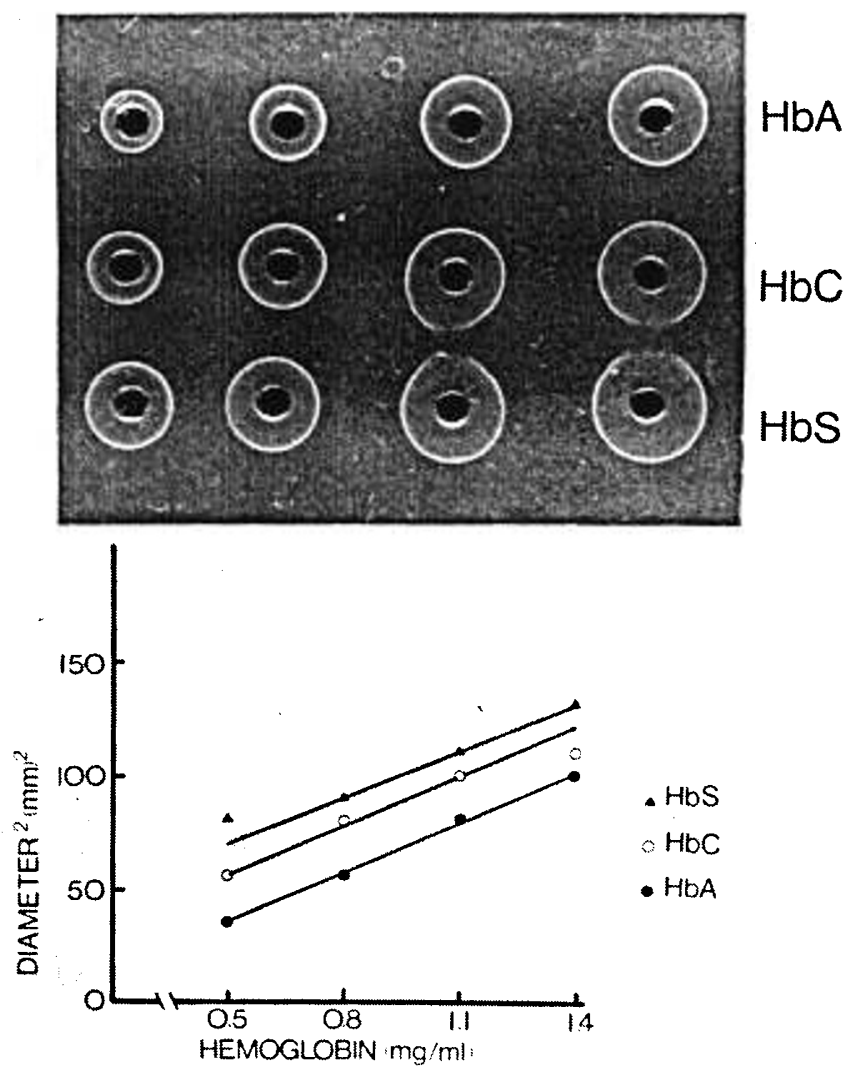

Fig. 2. Dose-response relationships by radial immunodiffusion between antibodies and purified hemoglobins in the range of concentrations anticipated in cord blood specimens. Specific antibodies for hemoglobins $\mathrm{A}, \mathrm{C}$, and $\mathrm{S}$ were mixed into agar at concentrations of $1.8,1.2$, and 0.6 $\mathrm{mg} / \mathrm{ml}$, respectively.

obtained by amniocentesis and in the corresponding maternal venous blood, as illustrated in Figures 4 and 5. Each spherical aggregate of immunoprecipitate granules corresponds to a single cell. On the basis of relative cell counts alone the fluid specimen shown in Figure 4 yields a presumptive diagnosis of $\mathrm{Hb}$ AS in the fetus. The maternal blood specimen is negative for $\mathrm{S}$ cells and this was confirmed by electrophoresis of hemolysate on cellulose acetate. The fluid specimen in Figure 5 yields a presumptive diagnosis of $\mathrm{Hb}$ SS in the fetus. It is negative for A cells and positive for S cells. These specimens demonstrate that the methodology possesses adequate sensitivity and specificity for $\mathrm{Hb} \mathrm{S}$ in cells from the midtrimester fetus.

Not all fluid specimens are free of maternal blood. Among 100 sequential amniotic fluid specimens, $41 \%$ were scored as containing visible indication of hemoglobin, ranging from mildly pink to red. Among 33 sequential pairs of amniotic fluid and maternal blood 29 showed a higher $\mathrm{F}$ cell to A cell ratio in amniotic fluid than in maternal blood. This confirms that a majority of fluid specimens contain red blood cells of fetal origin.

Since a substantial proportion of fluid specimens contain a mixture of maternal and fetal cells the following approach was devised for identifying fetal cells. Metabolically active red cells incubated with $\mathrm{L}-\left[{ }^{14} \mathrm{C}\right]$ serine and subsequently suspended in agar and incubated with anti-A conjugated with fluorescein isothiocyanate showed double labeling when autoradiography and fluorescence microscopy were combined. When incubation with $\mathrm{L}-\left[{ }^{14} \mathrm{C}\right]$ serine was omitted from the same specimens there were no autoradiograph patterns, confirming that there was no nonspecific discoloration of the film by nonradioactive cell contents (Fig. 6).

In an initial short series of red blood cells in amniotic fluid specimens taken at 18 weeks of gestation, the relative frequencies of fluorescent $A$ cells, $S$ cells, and. $F$ cells which also produced autoradiographic patterns typically exceeded those in maternal venous blood taken at the same gestational stage. Figure 7 depicts the double label pattern produced by cells from amniotic fluid and the accompanying single label pattern in maternal venous blood.

\section{DISCUSSION}

It is proposed that diagnosis of hemoglobin sickling phenotypes in cord blood by radial immunodiffusion lends itself to a testing strategy which provides diagnosis on all infants before they are discharged from the hospital, including hospitals with minimally equipped and staffed laboratories. Followup in newborn screening clinics in our own experience and that reported elsewhere (15) has reached only $30-40 \%$ of infants. This lends weight to the objective for making a diagnosis before discharge. In the American black population the predicted frequencies for major pathologic hemoglobin phenotypes have been reported as follows: $\mathrm{Hb}$ SS, 1/400; Hb SC, 1/1000; Hb S- $\beta$-thal, $1 / 2500$ (21).

One strategy for screening of these major hemoglobinopathies in the newborn infant is to perform hemoglobin electrophoresis for all women from populations at risk who present for delivery. Only for those mothers showing carrier or other states for a variant phenotype would the infant's cord blood be tested for a hemoglobinopathy. By this approach only about $10 \%$ of American black infants would require testing. Both the electrophoresis of maternal hemoglobin on cellulose acetate and the RID plate for cord blood are within the capability of laboratories in relatively small hospitals. Identification of matings at increased risk for producing future affected infants (mothers with sickle cell trait) as well as identification of affected infants is the payoff of the strategy proposed here. The approach may, however, miss detection of women with $\beta$-thalassemia trait and secondarily those infants with HbS- $\beta$-thal.

As an alternative strategy all infants would be screened by RID and secondarily both parents of infants with sickle cell disease or sickle cell trait would be offered testing by electrophoresis. In this latter strategy those infants with $\mathrm{Hb} \mathrm{AA}$ who are the product of a trait-X-trait mating do not lead to a diagnosis of this high risk mating. However, the principal objective of detecting all the indicated disease states is achieved by this strategy. This approach to diagnosis is now being tested on a large sample of infants at this medical center.

The RID method is obviously capable of detecting only hemoglobins for which antibodies are available. To date in our laboratory the antibodies are available for the hemoglobinopathies of substantial frequency (SS, SC, and S-thal). Antibodies for more rare variants have been reported (5), leading to an expectation that this diagnostic capability can be expanded. The RID method in a single operation can yield qualitative and quantitative diagnoses simultaneously for three hemoglobins. This feature holds promise for economy of effort. Although there has not been opportunity to test for homozygotes with $\beta$-thalassemia the quantitative sensitivity of the test system should allow this diagnosis.

Prenatal diagnosis should be available to any set of prospective parents who both know themselves to be carriers for a sickling disorder and who would voluntarily elect selective termination of pregnancy as an acceptable means of prevention. Clearly, the frequency with which this option will be utilized by prospective parents will be predicated on a number of variables, such as family structure, religious belief, cultural tradition, prior experience with sickle cell disease, etc. (18). The potential prospect of ameliorating sickle cell disease by enhancing $\mathrm{Hb} F$ synthesis also may require prenatal diagnosis in order to exercise effective intervention in the $\mathrm{Hb} \mathrm{F}$ regulation process at a sufficiently early stage. The diagnostic method presented here is adapted to a specimen sampling method which to date has shown no short term or intermediate term injury to the subsequently live born infants $(11,14,19)$. The method also 


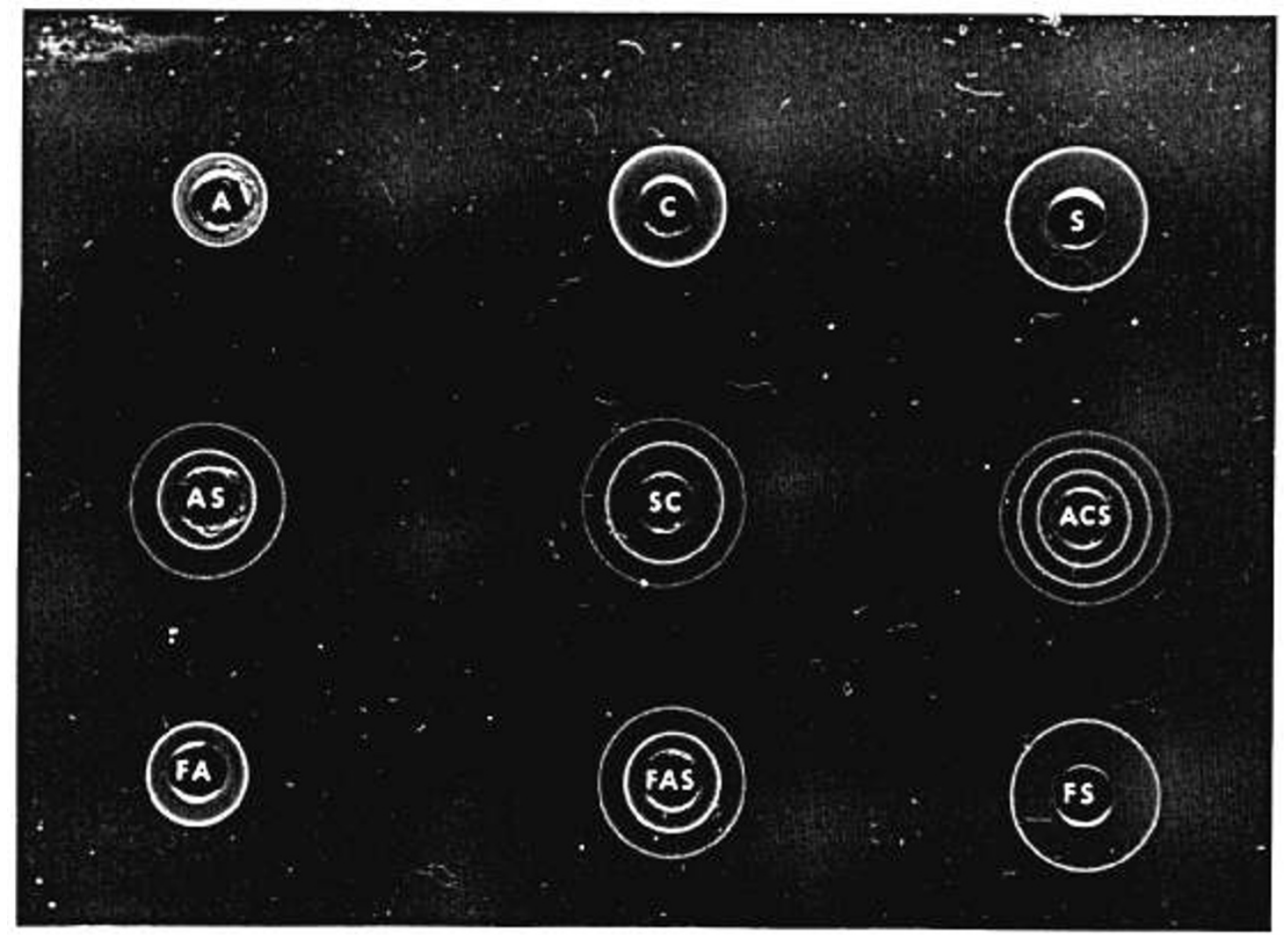

Fig. 3. Simultaneous identification of multiple hemoglobins in mixtures of purified hemoglobins in the first and second rows, and cord bloods in the third row. The agar plate contained a mixture of the three specific antibodies at concentrations of $1.8,1.2$, and $0.6 \mathrm{mg} / \mathrm{ml}$, respectively, for hemoglobins A, C, and S. Each of the purified hemoglobins was present at a concentration of $1 \mathrm{mg} / \mathrm{ml}$ (rows I and II).

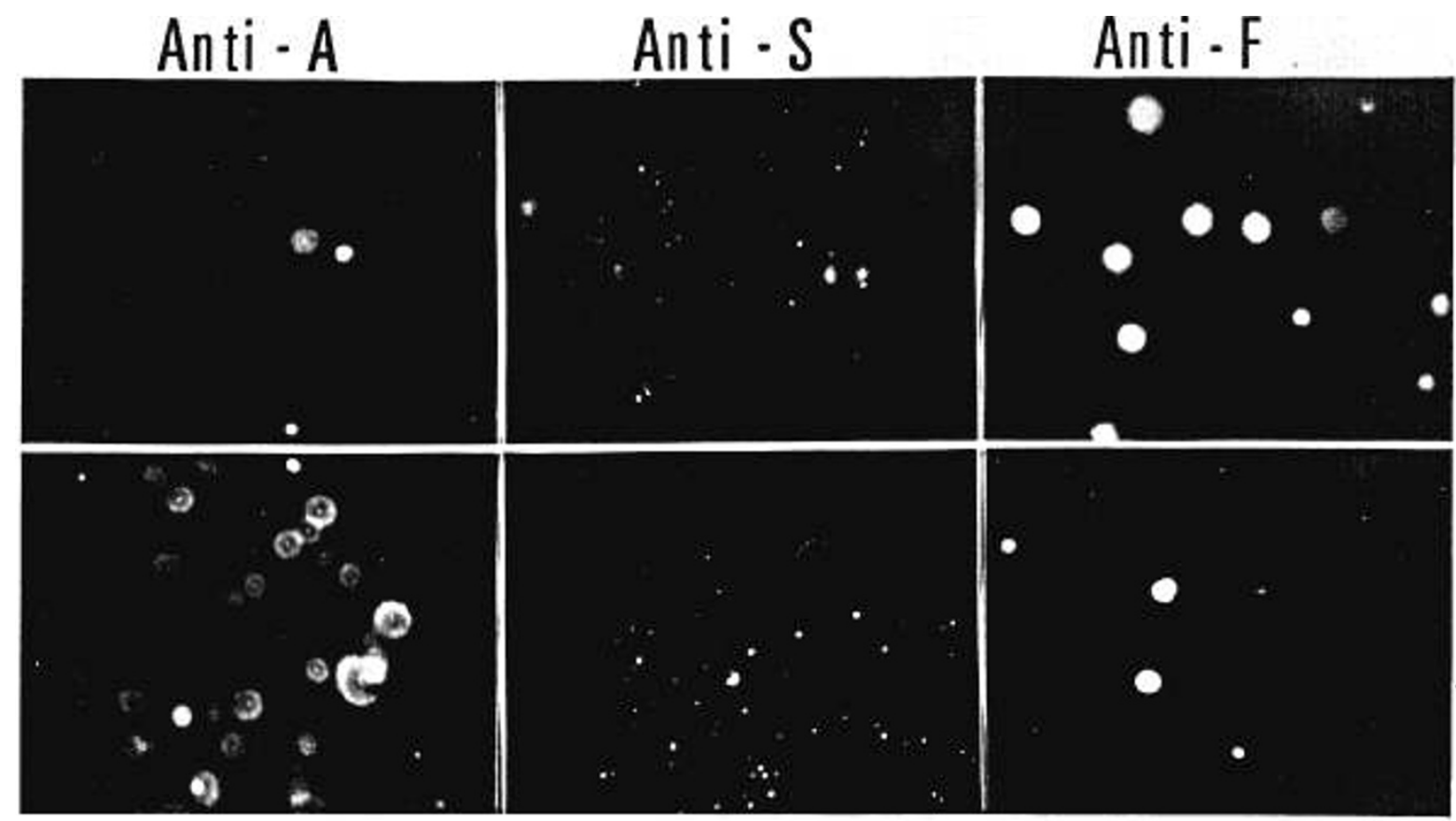

Fig. 4. Photomicrographs $(\times 72)$ of fluorescent cytoimmunodiffusion patterns for red blood cells in amniotic fluid (row I) and maternal venous blood (row II), both at 18 weeks of gestation. Maternal hemoglobin phenotype was confirmed to be A by electrophoresis on cellulose acetate.

secures red blood cells of fetal origin with about the same frequency as reported for endoscopy and attempted aspiration from a placental vein.

The specificity as well as sensitivity of the fluorescent antibodies appear to be adequate for making diagnoses of specific hemoglo- bins in cells at 18 weeks of gestation. At this stage the frequencies of circulating nucleated red corpuscles and reticulocytes are approximately 0.5 and $18 \%$, respectively (24), whereas reticulocyte counts in the adult are typically less than $2 \%$. Furthermore, the combined labeling of cells, as shown in Figure 7 , reveals that 
amniotic fluid contains a higher frequency of metabolically active cells which contain hemoglobin than occurs in maternal blood.

Diagnostic accuracy for the hemoglobin phenotypes of the fetus by the combination of autoradiography and fluorescent cytoimmunodiffusion is currently being tested in a substantial unselected sample of amniotic fluid specimens, by concurrent electrophoresis of hemoglobin from abortuses. The technique has not yet been applied to prospectively identified high risk matings for sickle cell disease. This study, however, does document adequate specificity and sensitivity for making this diagnosis. There is as yet no data on whether this method is sufficiently sensitive to diagnose homozygotes for $\beta$-thalassemia.

Criteria for definitive diagnosis of $\mathrm{Hb}$ SS in the fetus are red blood cells from amniotic fluid which include synthetically active $S$ cells, absence or rare occurrence of synthetically active A cells, and synthetically active $\mathrm{F}$ cells at relative frequencies higher than
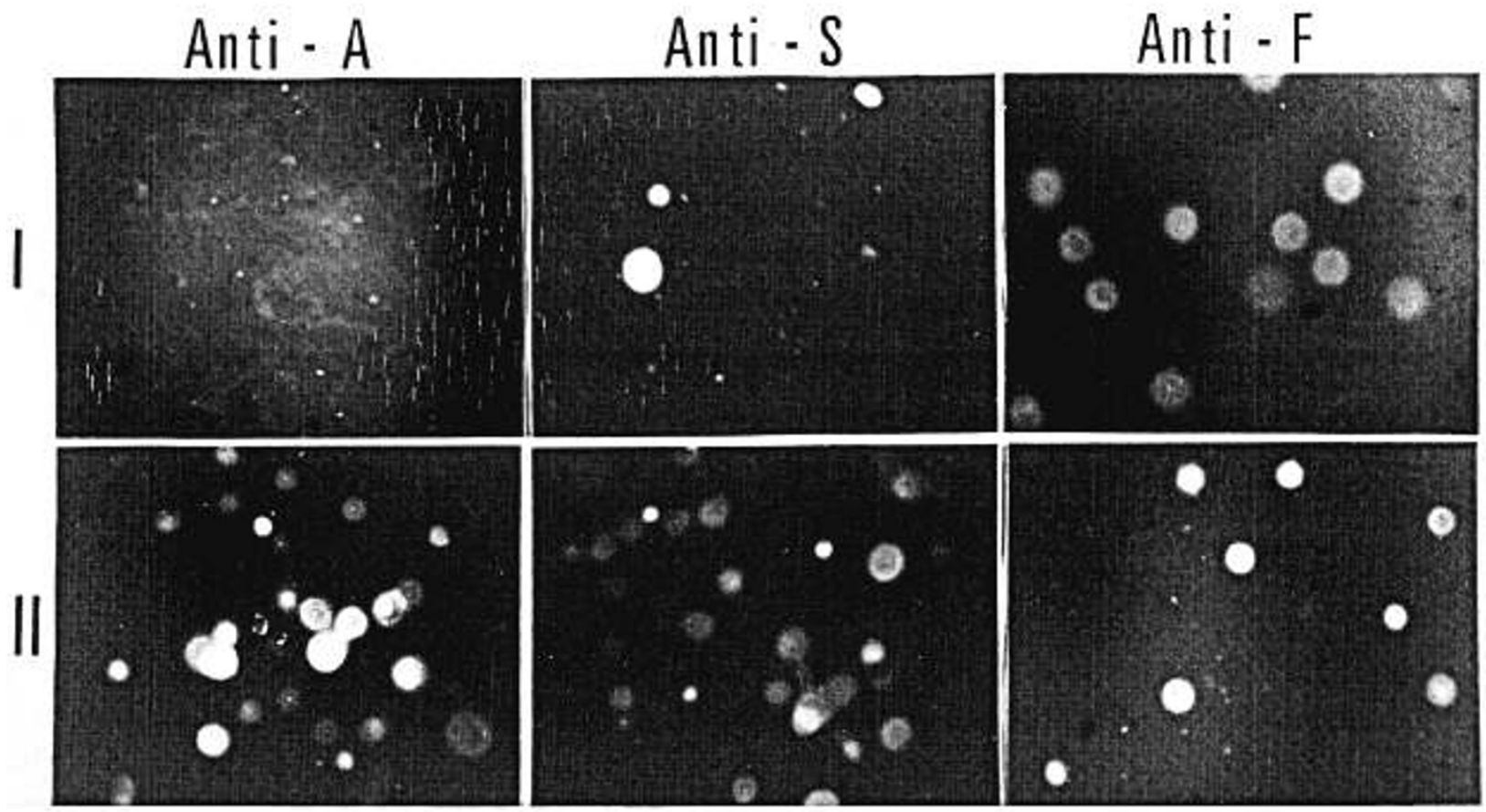

Fig. 5. Photomicrographs $(\times 72)$ of fluorescent cytoimmunodiffusion patterns for red blood cells in amniotic fluid (row I) and maternal venous blood (row II), both at 18 weeks of gestation. Maternal hemoglobin phenotype was confirmed to be AS by electrophoresis on cellulose acetate.
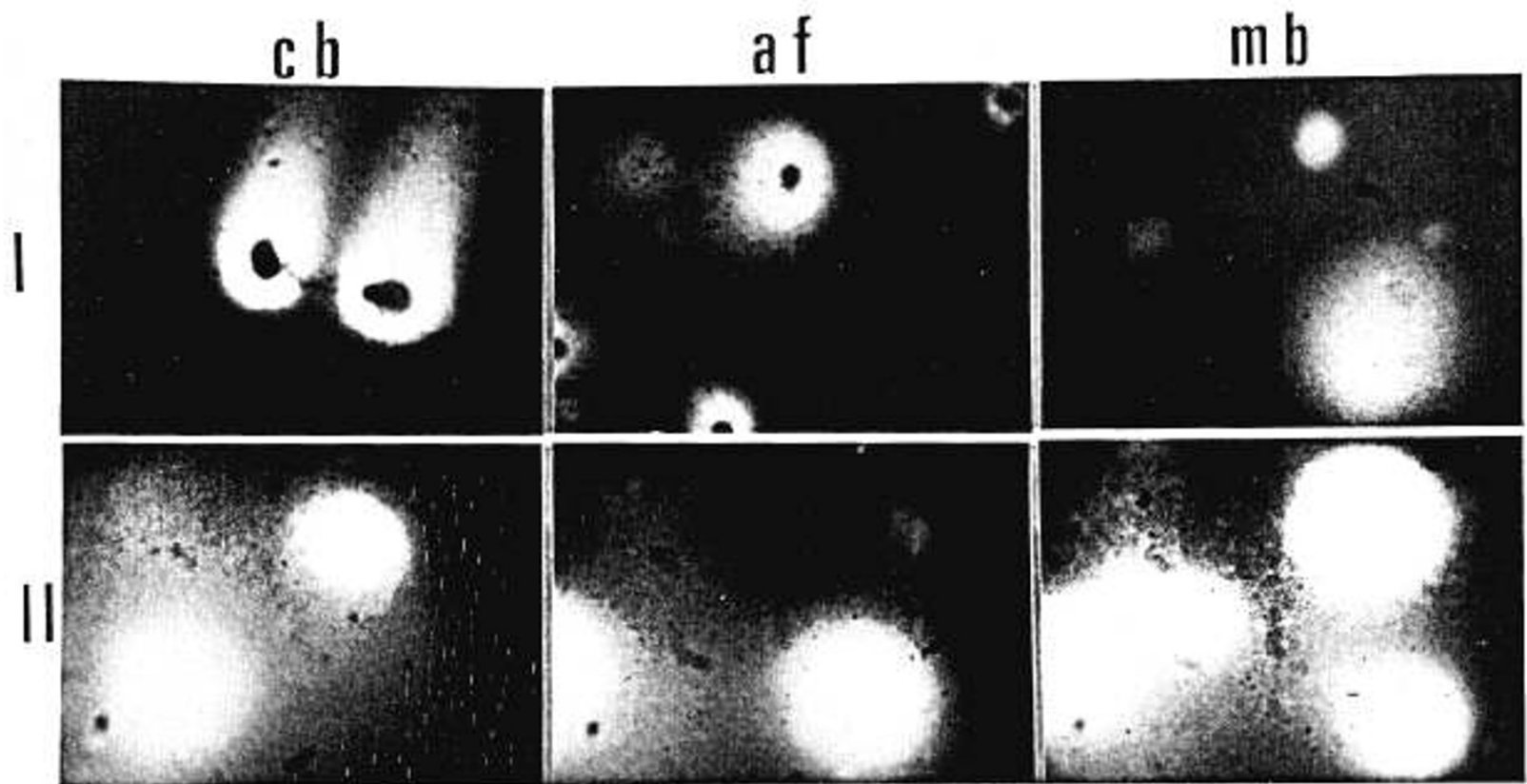

Fig. 6. Photomicrographs $(\times 72)$ of fluorescent cytoimmunodiffusion patterns with anti-A showing absence of false-positive interaction of cell content with Kodak NTB 3 emulsion. Cord blood (cb); amniotic fluid (af); maternal blood (mb); cells incubated with L- $\left[{ }^{14} \mathrm{C}\right]$ serine (I); cells incubated without L- $\left[{ }^{14} \mathrm{C}\right]$ serine (II). 

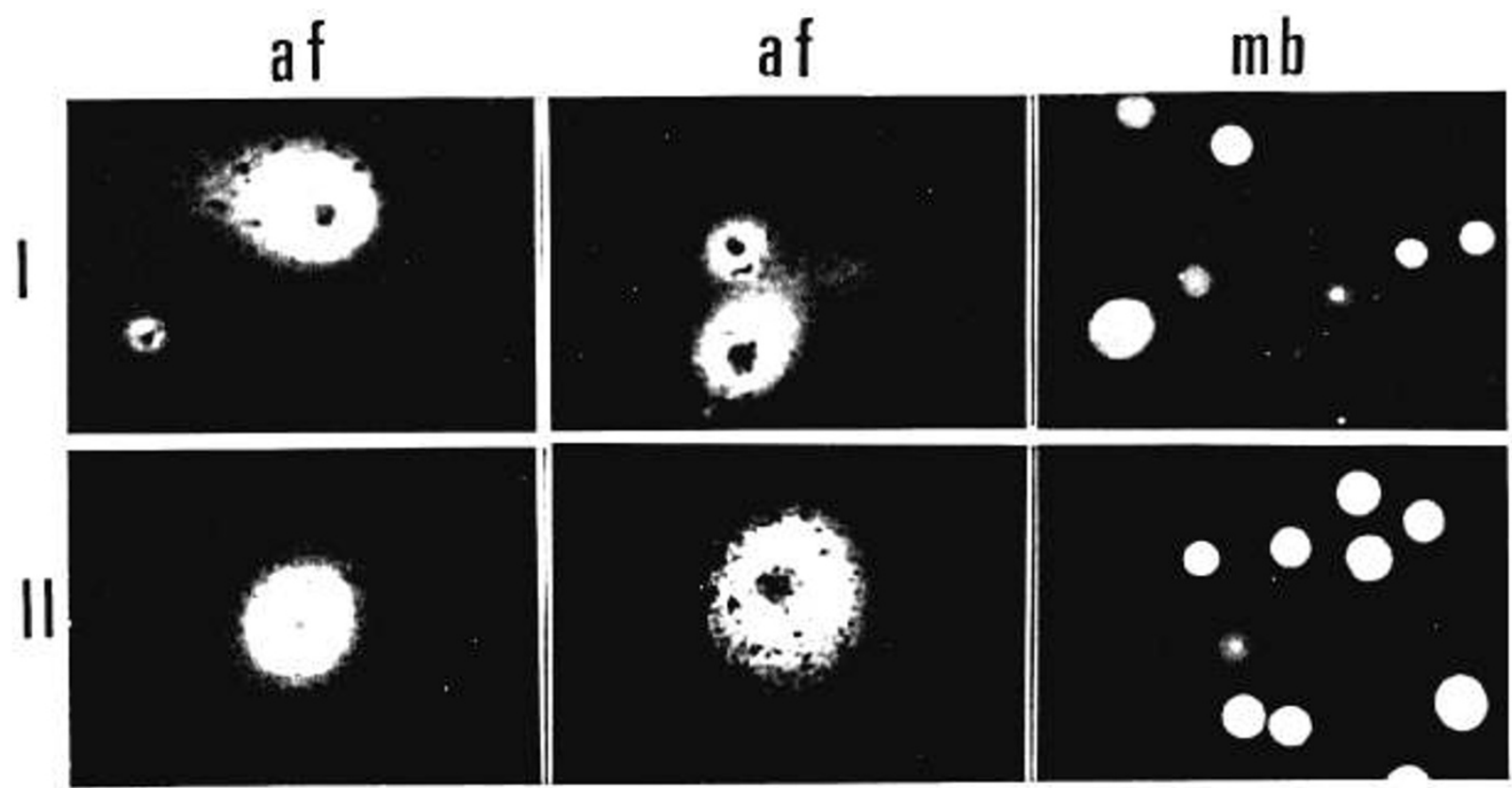

Fig. 7. Photomicrographs $(\times 72)$ showing double labeling of cell contents by L- $\left[^{14} \mathrm{C}\right]$ serine (autoradiography) and fluorescent cytoimmunodiffusion. Amniotic fluid (af); maternal venous blood (mb); fluorescent anti-A (I); fluorescent anti-S (II).

in maternal blood. The modest reticulocytosis in some pregnant women with thalassemia trait and sickle cell trait would rarely, if ever, simulate the fetal synthetically active $F$ cell frequency.

\section{CONCLUSION}

Specificity and sensitivity of antibodies to hemoglobin variants are shown to be adequate for diagnosing hemoglobinopathy phenotypes in the mid-trimester fetus and in the newborn infant. Furthermore, the laboratory requirements in both instances are less complex than other methods so far developed. For diagnosis in the fetus the small number of red blood cells required by the methodology circumvents the need to subject the fetus or mother to fetal blood sampling procedures which pose unacceptable risks.

\section{REFERENCES AND NOTES}

1. Alter, B. P., Modell, C. B., Fairweather, D., Hobbins, J. C., Mahoney, M. J. Frigoletto, F. D., Sherman, A. S., and Nathan, D. G.: Prenatal diagnosis of hemoglobinopathies: A review of 15 cases. N. Engl. J. Med., 295: 1437 (1976).

2. Anyaibe, S., and Headings, V.: Identification of hemoglobins in single erythrocytes by electrophoresis. Amer. J. Hematol., 2: 307 (1977).

3. Boyer, S. H., Boyer, M. L., Noyes, A. N., and Belding, T. K.: Immunological basis for detection of sickle cell hemoglobin phenotypes in amniotic nuid erythrocytes. Ann. N. Y. Acad. Sci., 241: 699 (1974).

4. Garrick, M. D., Dembure, P., and Guthrie. R.: Sickle cell anemia and other hemoglobinopathies: Procedures and strategy for screening employing spots of blood on filter paper as specimens. N. Engl. J. Med., 288: I265 (1973).

5. Garver, F. A., Baker, M. B., Jones, C. S., Gravely, M., Altay, G., and Huisman, T. H.: Radioimmunoassay for abnormal hemoglobins. Science, 196: 1334 (1977).

6. Garver, F. A., Jones, C. S., Baker, M. M., Altay, G., Barton, B. P., Gravely, M. and Huisman, T. H. J.: Specific radioimmunochemical identification and quantitation of hemoglobins $A_{2}$ and F. Amer. J. Hematol., $1: 459$ (1976).

7. Headings, V., Bhattacharya, S., Anyaibe, S., Easton, L., Shukla, S., Scott, R., and Hopkins, E.: Exploratory studies on detection of hemoglobins in the early human fetus in utero. Ann. N. Y. Acad. Sci., 241: 714 (1974).

8. Headings, V., Bhattacharya, S., Shukla, S., Anyaibe, S., Easton, L., Calvert, A., and Scott, R.: Identification of specific hemoglobins within individual erythrocytes. Blood, 45: 263 (1975).

9. Headings, V., and Scolt, R.: Current and potential options for preventing occurrence of hemoglobinopathies. Southern Med. J., 68: 1429 (1975).
10. Headings, V. E., Shukla, S. B., Bhattacharya, S. P., and Anyaibe, S. I. O.: Identification and quantitation of hemoglobins by immunochemical techniques. Proceedings of the First National Symposium on Sickle Cell Disease, Bethesda, MD. DHEW Pub. No. (NIH) 75-723, 1974, p. 97.

11. Hirschhorn, K.: The role and the hazards of amniocentesis. Ann, N. Y. Acad. Sci., 240: 117 (1975).

12. Hobbins, J. C., and Mahoney, M. J.: Fetal blood drawing. Lancet, $i: 107$ (1975).

13. Hollenberg, M. D., Kaback, M. M., and Kazazian, H. H., Jr.: Adult hemoglobin synthesis by reticulocytes from the human fetus at midtrimester. Science, 174: 698 (1971).

14. Hsu, L.. Yahr, F., Godmilow, L., and Hirschhorn, K.: Amniocentesis for prenatal diagnosis. The Lancet, i: 206 (1976).

15. Huntsman, R. G. Metters, J. S., and Yawson. G. I.: The diagnosis of sickle cell disease in the newborn infant. J. Pediat. 80: 279 (1972).

16. Kan. Y. W., Dozy, A. M., Alter, B. P., Frigoletto, F. D., and Nathan. D. G.: Detection of the sickle gene in the human fetus. N. Engl. J. Med., 287: I (1972).

17. Kan, Y. W., Golbus, M. S., Trecartin, R. F., Filly, R. A., Valenti, C., Furbetta M., and Cao, A.: Prenatal diagnosis of $\beta$-thalassemia and sickle-cell anaemia: Experience with 24 cases. Lancet, i: 269 (1977).

18. Konotey-Ahulu, F. I. D.: Antenatal diagnosis of haemoglobinopathies. Lancet, i: 597 (1977).

19. Munk-Andersen, E., Weber, J., and Mikkelsen, M.: Amniocentesis in prenatal diagnosis: A controlled series of 78 cases. Clin. Genet., II: 18 (1977).

20. Powars, D., Schroeder, W. A., and White, L.: Rapid diagnosis of sickle celt disease at birth by microcolumn chromatography. Pediatrics, 55: 630 (1975).

21. Rucknagel, D. L. and Laros, R. K., Jr.: Hemoglobinopathies: Genetics and implications for studies of human reproduction. Clin. Obstet. Gynecol., 12: 49 (1969).

22. Serjeant, B. E., Forbes, M., Williams, L. L., and Serjeant, G. R.: Screening cord blood for detection of sickle cell disease in Jamaica. Clin. Chem., 20: 666 (1974).

23. Shukla, S., and Headings, V.: Quantitation of hemoglobins by immunodiffusion: Specific antibodies to hemoglobins $A_{1}, S$ and $F$. Immunochemistry, $11: 741$ (1974).

24. Wintrobe, M.: Clinical Hematology, Ed. 2 (Lea \& Febiger, Philadelphia, 1967).

25. Written informed consent was obtained from individuals from whom blood and amniotic fluid were obtained.

26. This research was supported by a grant from the John A. Hartford Foundation and Grant HL-15160 from the NIH.

27. Requests for reprints should be addressed to: Dr. Verle E. Headings, Division of Medical Genetics, Box 75, Howard University College of Medicine, Washington, DC 20059 (USA).

28. Received for publication May 31, 1977.

29. Accepted for publication November 16, 1977. 